https://doi.org/10.15407/dopovidi2020.07.043

UDC 612.67:577.24[546.65:66.-911.48]

\author{
Yu.V. Nikitchenko ${ }^{1}$, V.K. Klochkov ${ }^{2}$, N.S. Kavok ${ }^{2}$, \\ N.A. Karpenko ${ }^{2}$, O.O. Sedyh ${ }^{2}$, A.I. Bozhkov ${ }^{1}$, \\ Yu.V. Malyukin $^{2}$, V.P. Seminozhenko ${ }^{2}$ \\ ${ }^{1}$ Biology Research Institute, V.N. Karazin Kharkiv National University \\ ${ }^{2}$ Institute for Scintillation Materials, SIC "IMK" of the NAS of Ukraine, Kharkiv \\ E-mail:kavok@isma.kharkov.ua
}

\title{
Orthovanadate nanoparticles delay the accelerated aging in rats via the prevention of oxidative disturbances
}

\author{
Presented by Academician of the NAS of Ukraine V.P. Seminozhenko
}

The abilities of gadolinium orthovanadate nanoparticles $\left(G d V O_{4}: E u^{3+} \mathrm{NPs}, 8 \times 25 \mathrm{~nm}\right)$ to ameliorate age-related lesions have been studied. To achieve the goal, a model of accelerated aging due to postnatal overfeeding (POF) was used. The features of the model are oxidative misbalance and decrease in survival, as well as adverse metabolic effects. The NPs were orally administrated (briefly or continuously) with drinking water to rats with accelerated aging. Then the prooxidant-antioxidant balance (in liver and blood), survival, and life expectancy were examined. In young (3 months-old) rats with accelerated aging, already the short-term (2 months) NPs implementation significantly corrects the oxidative disturbance. The prolonged use of NPs from 11 to 31 months of life ameliorates significantly the prooxidant-antioxidant misbalance in the liver and blood of POF rats. Wherein, the observed median of survival in the control group is 890 days, in the group with accelerated aging - only 710 days, while the additional receive of NPs increases the score - already 940 days. Furthermore, the death of the last animal in the control group is observed by day 1130, at accelerated aging - by day 1000, and at accelerated aging with additional NPs using - by day 1250. Thus, the both indicators - the survival and the lifespan, are increased due to the NPS applications by $32 \%$ and 25\%, respectively, compared with the accelerated ageing group, which receives no NPs.

The obtained data show that the prolonged $\mathrm{GdVO}_{4}: \mathrm{Eu}^{3+} \mathrm{NPS}$ application in animals with experimental accelerated aging corrects the oxidative misbalance as well as increases the survival of elderly animals. Discovered effects make these nanoparticles a promising geroprotective agent, decreasing the risk of increased mortality and morbidity at premature ageing - adverse consequences of the overnutrition in early life.

Keywords: $\mathrm{GdVO}_{4}: \mathrm{Eu}^{3+}$ nanoparticles, early postnatal overfeeding, accelerated aging, prooxidant-antioxidant balance, survival, lifespan, male rats.

Introduction. Experimental data accumulated to date indicate a significant role of free radical processes in organism senescence. According to the literature, nutrition is one of the most important factors defining the prooxidant-antioxidant state and the life expectancy of mammals [1-3].

Ц и т у в а н н я: Nikitchenko Yu.V., Klochkov V.K., Kavok N.S., Karpenko N.A., Sedyh O.O., Bozhkov A.I., Malyukin Yu.V., Seminozhenko V.P. Orthovanadate nanoparticles delay accelerated aging in rats via prevention of oxidative disturbances. Допов. Наи. акад. наук Укр. 2020. № 7. С. 43-51. https://doi.org/10.15407/dopovidi2020.07.043 
In particular, numerous data indicate that the use of a calorie-restricted diet, which increases the life span of animals, leads to a decrease in reactive oxygen species (ROS), a lowering freeradical damage of biomolecules, and an increase in the activity of a number of antioxidant enzymes in a cell $[2,4,5]$. Opposite changes were found, when rats were overfed during lactation (postnatal overfeeding, POF) $[4,6,7]$. In particular, we previously showed that the intensity of the generation of superoxide radicals by liver microsomes and the level of lipid hydroperoxides (LHPO) in blood serum and liver significantly increased in response to excessive nutrition in the early postnatal ontogenesis. At the same time, the activities of antioxidant enzymes such as superoxide dismutase and glutathione peroxidase in liver and blood were decreased [4]. In addition, the survival of 31-month-old experimental (POF) rats was almost 2 times lower than in control rats of the same age [7]. Thus, the accelerated aging model allows examining the anti-aging effects of various compounds. In addition, excess nutrient supply during early life is linked to the increased risk of adult obesity and its associated adverse metabolic health problems. In this regard, the POF model is relevant to study the metabolic programming of illness, as well as the physiological mechanisms of accelerated aging involving the prooxidant-antioxidant system.

We earlier showed that the use of $\mathrm{GdVO}_{4}: \mathrm{Eu}^{3+} \mathrm{NPs}$ with drinking water $(0.25-0.3 \mathrm{mg} / \mathrm{kg}$ body weight per day) from 22 months of age leads to the significant increase in survival, a lower rectal temperature, and a slower decrease in the thyroxine level in blood, as well as to the normalization of the prooxidant-antioxidant balance in liver and blood in rats [8]. The data suggest that the NPs application may normalize the prooxidant-antioxidant balance in senescent rats and improve their survival.

The aim of this work is to reveal $\mathrm{GdVO}_{4}: \mathrm{Eu}^{3+} \mathrm{NPs}$-induced improvements of prooxidant/ antioxidant balance and survival in animals with experimental accelerated ageing due to early overfed during lactation.

Materials and methods. In the present research, $\mathrm{GdVO}_{4}: \mathrm{Eu}^{3+} \mathrm{NPs}$ were used. The hydrosol of gadolinium orthovanadate nanoparticles doped with europium ions $\mathrm{Gd} 0.9 \mathrm{Eu} 0.1 \mathrm{VO}_{4}$ $\left(\mathrm{GdVO}_{4}: \mathrm{Eu}^{3+}\right)$ was synthesized as described previously [9]. To a mixture of aqueous $1 \mathrm{M}$ gadolinium chloride $(0.4 \mathrm{ml})$ and $1 \mathrm{M}$ europium chloride $(0.05 \mathrm{ml})$, we added $49.55 \mathrm{ml}$ of bidistilled water and then dropwise: a) $37.5 \mathrm{ml}$ disodium EDTA solution $(0.01 \mathrm{M})$ and b) $37.5 \mathrm{ml}$ of $\mathrm{Na}_{3} \mathrm{VO}_{4}$ $(0.01 \mathrm{M})(\mathrm{pH}=10.5)$. After a vigorous stirring, the mixture was heated in a water bath under reflux condenser for $24 \mathrm{~h}$ at $100{ }^{\circ} \mathrm{C}$. The obtained colorless transparent solution scatters light under lateral illumination (the Tyndall cone). The cooled solution was dialyzed against water for $24 \mathrm{~h}$ to remove excess ions (dialysis sac Cellu Sep T2, membrane with a molecular weight cutoff of $12 \mathrm{kDa}$, pore size $\sim 2.5 \mathrm{~nm}$ ) with a change of water every $6 \mathrm{~h}$. The nanoparticles were characterized using a TEM-125K transmission electron microscope (Selmi, Ukraine) [10]. NPs of $\mathrm{GdVO}_{4}: \mathrm{Eu}^{3+}$ have a spindle shape and are $(8 \times 25) \mathrm{nm}$ in size. The hydrodynamic diameter $(56 \pm 1.5 \mathrm{~nm})$ and zeta potential $(-20.00 \pm 2.00 \mathrm{mV})$ of EDTA coated NPs were measured using ZetaPALS (Brookhaven, New York). The concentration of NPs in the hydrosol was determined from the absorption spectra at $279 \mathrm{~nm}$ on a Specord 200 spectrophotometer [10].

Investigations were performed on males of Wistar rats maintained under standard vivarium conditions in accordance with the guidelines of the European Convention for the Protection of the Vertebrata using for the Experimental and Scientific Purposes (1986). 
In the first experiment, on the third day after childbirth, the female and the pups were divided into a control group (normal feeding, NF) or a group with postnatal overfeeding (POF). Litter sizes were adjusted to 8 pups for the NF group or reduced to 2 pups to induce the postnatal overfeeding in the lactation period.

From 1 month to 3 months of life, animals of both groups were kept in standard conditions and on standard diet. At the age of 3 months, POF rats were divided up on subgroups: POF and POF+NPs. During 2 months, animals from groups NF ( 7 rats) and POF ( 7 rats) were giving drinking water without any additives, while rats of $\mathrm{POF}+\mathrm{NPs}$ group ( 7 rats) were giving drinking water with $\mathrm{GdVO}_{4}: \mathrm{Eu}^{3+} \mathrm{NPs}$ in dose $0.25-0.30 \mathrm{mg} / \mathrm{kg}$ body mass in a day. At the age of 5 months, rats were quickly decapitated to study the pro-/antioxidant balance in different tissues.

The second experiment was performed on rats at the age of 330 days of the following groups: NF (normal early feeding, 38 rats), POF (67 rats) and POF+NPs (49 rats). In the last group, rats were giving drinking water with $\mathrm{GdVO}_{4}: \mathrm{Eu}^{3+} \mathrm{NPs}$ in a same dose to the end of life.

At the age of 930-940 days, 6 animals from each group were scarified, and the state of pro/antioxidant balance was investigated. The duration of the treatment with NPs was about 20 months.

Microsomal (MSF), mitochondrial (MF), postmitochondrial (PMF) fractions of liver, as well as liver cytosol $(\mathrm{C})$, were obtained by differential centrifugation immediately after necropsy. These samples, as well as serum $(\mathrm{S})$ and liver homogenate $(\mathrm{H})$, were either analyzed immediately (lipid hydroperoxide, LHPO), or stored in liquid nitrogen till the analysis.

The parameters of the prooxidant-antioxidant balance were measured using the methods described by us earlier $[4,5,7,11]$. LHPO content in liver was determined by the method of Ohkawa et al. (1979), and in serum - by the method of Asakawa et al. (1980) spectrophotometrically (UV VIS, Germany). Aconitase activity (Aco) (EC 4.2.1.3) was determined in MF with spectrophotometry at $240 \mathrm{~nm}$, as described by Varghese (2003) with minor changes. The generation of superoxide radicals in MF was determined by the method of Misra and Fridovich (1972). Glutathione peroxidase (GPx) activity in liver fractions and homogenate was measured in a reaction coupled with exogenous glutathione reductase (oxidation substrates: cumene hydroperoxide (CHP) and $\mathrm{H}_{2} \mathrm{O}_{2}$ ) spectrophotometrically at $340 \mathrm{~nm}$ by the method of Paglia and Valentine (1967). Glutathione reductase (GR) activity in MF and PMF was determined by oxidation of NADPH spectrophotometry at $340 \mathrm{~nm}$ according to the method of Carlberg (1975). Glucose-6-phosphate dehydrogenase (G-6-PDG) activity, NADP-dependent isocitrate dehydrogenase (ICDG) activity, and NADP-dependent malate dehydrogenase (MDG) activity were investigated by the restoration of $\mathrm{NADP}^{+}$according to the methods of Zaheer (1967), Bauman (1970), Usatenko (1974). Superoxide reductase (SOD) activity by the method of Beauchamp \& Fridovich (1971) and catalase activity by the method of Aebi H. (1984) were measured. Content of GSH was estimated by Akerboom T.P.M., Sies H. (1981). Protein content was determined by the Lowry method in the modification of Miller (1959).

The obtained results were processed with the Student's t-test using the "Statistika V.6" computer software package. Analysis for survival was performed using the Kaplan-Meyer test. Survival curves were compared using the Gehan method with Yates correction. All data were expressed as mean \pm SEM. Significance level was set at $p<0.05$ ). 
Yu.V. Nikitchenko, V.K. Klochkov, N.S. Kavok, N.A. Karpenko, O.O. Sedyh, A.I. Bozhkov, Yu.V. Malyukin...
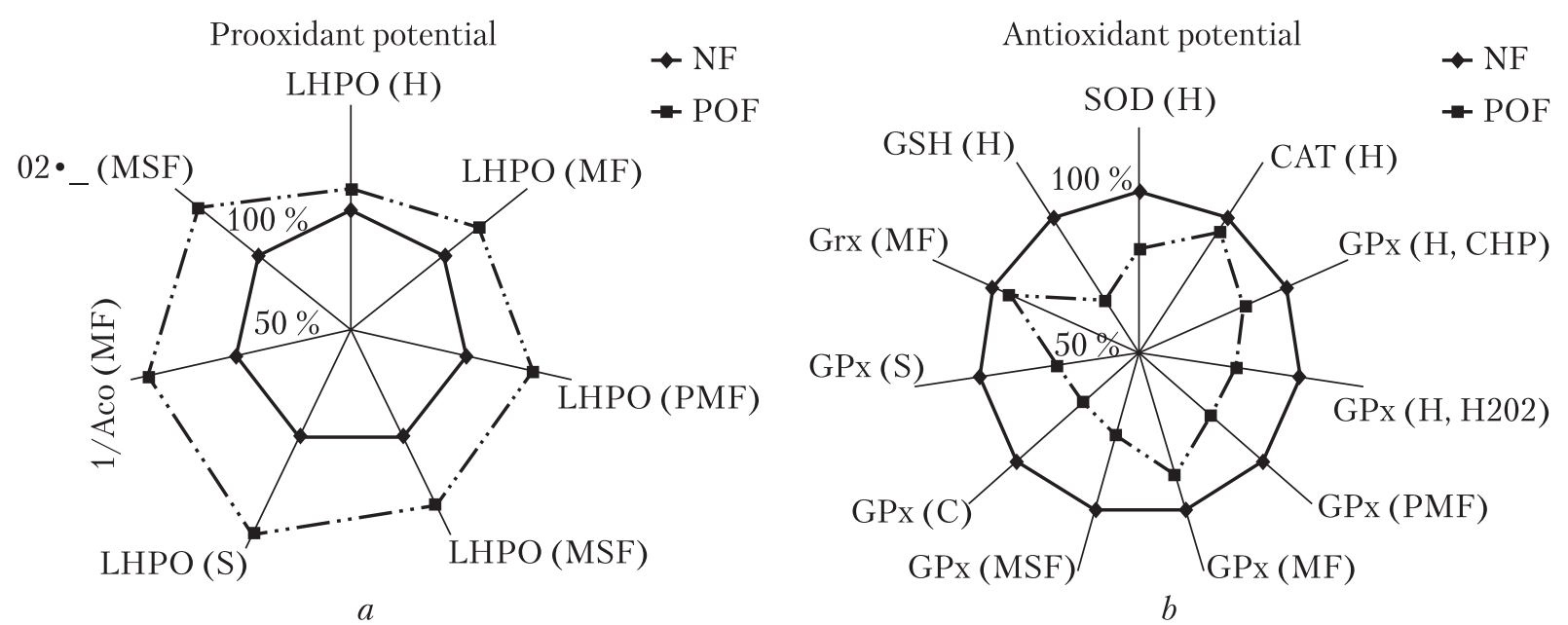

Fig. 1. Prooxidant $(a)$ and antioxidant $(b)$ potentials in serum and liver of young rats, early overfed during lactation $(n=7)$.

NF group prooxidant indicators $(100 \%)$ :

$\mathrm{LHPO}_{(\mathrm{H})}: 0.260 \pm 0.0131 \mathrm{nmol} \mathrm{MDA} \cdot \mathrm{ml}^{-1} ; \mathrm{HLPO}_{(\mathrm{MF})}: 0.387 \pm 0.014 \mathrm{nmol} \mathrm{MDA} \cdot \mathrm{mg}$ protein ${ }^{-1}$; $\mathrm{HLPO}_{(\mathrm{PMF})}: 0.154 \pm 0.05 \mathrm{nmol} \mathrm{MDA} \cdot \mathrm{mg}_{\operatorname{protein}^{-1}}$ HLPO $_{(\mathrm{MSF})}: 0.316 \pm 0.26 \mathrm{nmol} \mathrm{MDA} \cdot \mathrm{mg} \mathrm{C}$;

$\mathrm{HLPO}_{(\mathrm{S})}: 2.72 \pm 0.15 \mathrm{nmol} \mathrm{MDA} \cdot \mathrm{ml}^{-1} ; \mathrm{Aco}_{(\mathrm{MF})}: 33.54 \pm 1.64 \mathrm{nmol}$ aconitate $\cdot \mathrm{min}^{-1} \cdot \mathrm{mg}^{-1}$ protein $^{-1}$;

$\mathrm{O}_{2}^{-\bullet}$ (MSF) $: 28.7 \pm 2.1 \mathrm{nmol} \mathrm{O}_{2}^{-\bullet} \cdot \mathrm{min}^{-1} \cdot \mathrm{mg}^{-}$protein $^{-1}$;

NF group antioxidant indicators:

$\operatorname{SOD}_{(\mathrm{H})}: 621.4 \pm 28.6$ c.u. (conventional units) $\cdot \mathrm{mg} \operatorname{protein}^{-1}{ }^{-} \mathrm{CAT}_{(\mathrm{H})}: 320.3 \pm 23.6 \mu \mathrm{mol} \mathrm{H}_{2} \mathrm{O}_{2} \cdot \mathrm{min}^{-1} \cdot \mathrm{mg}^{-1}$ protein $^{-1}$ $\mathrm{GPx}_{(\mathrm{H}, \mathrm{CHP})}: 212.5 \pm 8.9 \mathrm{nmol} \mathrm{NADPH} \cdot \mathrm{min}^{-1} \cdot \mathrm{ml}^{-1} ; \mathrm{GPx}_{(\mathrm{H}, \mathrm{H} 2 \mathrm{O} 2)}: 46.0 \pm 2.5 \mathrm{nmol} \mathrm{NADPH} \cdot \mathrm{min}^{-1} \cdot \mathrm{ml}^{-1}$;

$\operatorname{GPx}_{(\mathrm{PMF}, \mathrm{H} 2 \mathrm{O} 2)}: 138.4 \pm 12.3 \mathrm{nmol} \mathrm{NADPH} \cdot \mathrm{min}^{-1} \cdot \mathrm{ml}^{-1} ; \mathrm{GPx}_{(\mathrm{MF})}: 61.6 \pm 5.7 \mathrm{nmol} \mathrm{NADPH} \cdot \mathrm{min}^{-1} \cdot \mathrm{mg} \mathrm{protein}^{-1}$; $\mathrm{GPx}_{(\mathrm{MSF}, \mathrm{CHP})}: 78.9 \pm 3.7 \mathrm{nmol} \mathrm{NADPH} \cdot \mathrm{min}^{-1} \cdot \mathrm{mg} \operatorname{protein}^{-1} ; \mathrm{GPx}_{\left(\mathrm{C}, \mathrm{H}_{2} \mathrm{O}_{2}\right.}: 547.9 \pm 3.91 \mathrm{nmol} \mathrm{NADPH} \cdot \mathrm{min}^{-1} \cdot \mathrm{mg}$ protein $^{-1}$; $\operatorname{GPx}_{(\mathrm{S}, \mathrm{H} 2 \mathrm{O} 2}: 1.54 \pm 0.11 \mu \mathrm{mol} \mathrm{NADPH} \cdot \mathrm{min}^{-1} \cdot \mathrm{ml}^{-1}$ Grx $_{(\mathrm{MF})}: 7.25 \pm 0.5 \mathrm{nmol} \mathrm{NADPH} \cdot \mathrm{min}^{-1} \cdot \mathrm{mg} \mathrm{protein}^{-1}$;

$\mathrm{GSH}_{(\mathrm{H})}: 5.79 \pm 0.61 \mu \mathrm{mol} \mathrm{GSH} \cdot \mathrm{g}^{-1}$

Results and Discussion. Earlier, in a series of works on the modeling of accelerated aging by POF (as described above), we showed the failure of a balance of prooxidant-antioxidant processes and the increase in mortality of laboratory animals [4, 7].

Summarized data on changes in prooxidant (Fig. 1A) and antioxidant processes (Fig. 1B) in young animals with POF are presented graphically. It is demonstrable that a prooxidant potential increased and antioxidant potential decreased significantly in young animals that were early overfed during lactation. Thus, the POF-induced prooxidant-antioxidant misbalance, which is the main factor in the reduction in life span, requires additional correction. A promising approach to solving this problem may be the use of NPs with antioxidant properties.

$\mathrm{GdV0}_{4}: \mathrm{Eu}^{3+} \mathrm{NPs}$ exerted antiradical, antioxidant, and membrane-protective properties in vitro, as well as anti-ageing effects in vivo [8, 12], so it is logical to assume that NPs might prevent the prooxidant-antioxidant misbalance at the presenilation produced by excessive nutrition during early postnatal ontogenesis.

In the case of the use of $\mathrm{GdVO}_{4}: \mathrm{Eu}^{3+} \mathrm{NPs}$ in 5 months age rats for 2 months, the level of LHPO in the serum and MF decreases (Fig. 2). At the same time, Aco activity in the liver MF is normalized.

Fig. 1 shows that the activity of serum GPx, liver MF and PMF of the POF rats is significantly lower than in animals with normal nutrition. However, the 2-month treatment of $\mathrm{GdV0}_{4}: \mathrm{Eu}^{3+} \mathrm{NPs}$ led to an increase in the enzyme activity in these fractions (Fig. 2). 


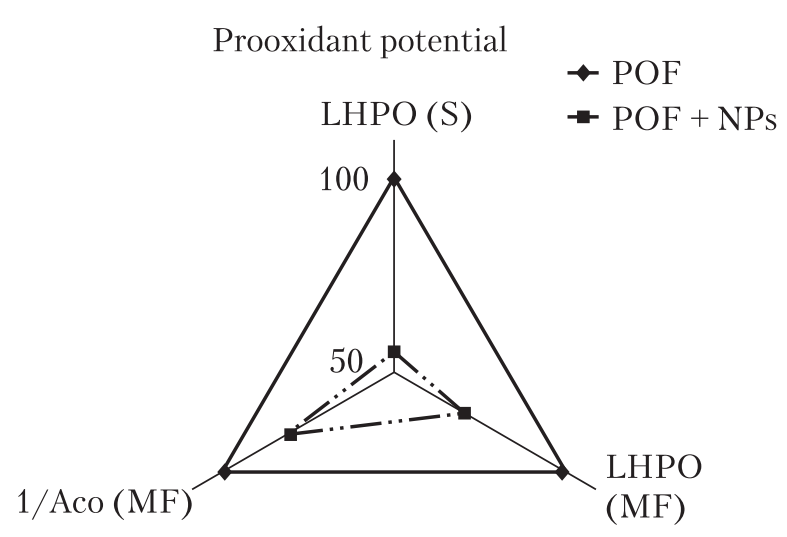

$a$

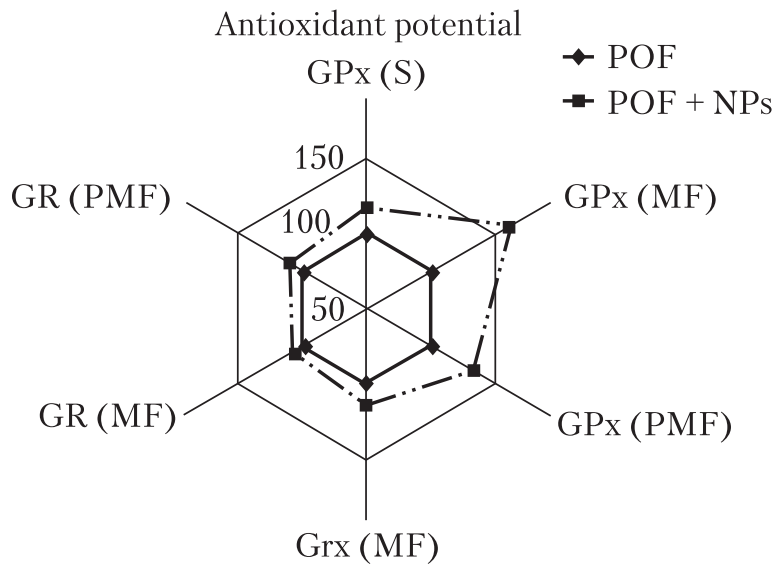

$b$

Fig. 2. Prooxidant $(a)$ and antioxidant $(b)$ potentials in serum and liver of 5 months rats with early overfeeding during lactation (POF, $n=7$ ) after the use of $\mathrm{GdVO}_{4}: \mathrm{Eu}^{3+} \mathrm{NPs}$ for 2 months from 3 months of age (POF $+\mathrm{NPs}$, $n=7$ ).

POF group prooxidant indicators (100\%):

$\mathrm{LHPO}_{(\mathrm{S})}: 4.45 \pm 0.27 \mathrm{nmol} \mathrm{MDA} \cdot \mathrm{ml}^{-1} ; \mathrm{LHPO}_{(\mathrm{MF})}: 0.461 \pm 0.019 \mathrm{nmol} \mathrm{MDA} \cdot \mathrm{mg} \operatorname{protein}^{-1}$; $\mathrm{AcO}_{(\mathrm{MF})}: 24.32 \pm 2.20 \mathrm{nmol}$ aconitate $\cdot \mathrm{min}^{-1} \cdot \mathrm{mg}$ protein ${ }^{-1}$;

POF group antioxidant indicators (100\%):

$\mathrm{GPx}_{(\mathrm{S}, \mathrm{H} 2 \mathrm{O} 2}: 4.01 \pm 0.30 \mu \mathrm{mol} \mathrm{NADPH} \cdot \mathrm{min}^{-1} \cdot \mathrm{ml}^{-1} ; \mathrm{GPx}_{(\mathrm{MF})}: 109.1 \pm 14.9 \mathrm{nmol} \mathrm{NADPH} \cdot \mathrm{min}^{-1} \cdot \mathrm{mg} \operatorname{protein}^{-1}$; $\mathrm{GPx}_{(\mathrm{PMF})}: 313.2 \pm 38.7 \mathrm{nmol} \mathrm{NADPH} \cdot \mathrm{min}^{-1} \cdot \mathrm{mg} \operatorname{protein}^{-1}{ }^{-\mathrm{Grx}_{(\mathrm{MF})}}: 6.85 \pm 0.82 \mathrm{nmol} \mathrm{NADPH} \cdot \mathrm{min}^{-1} \cdot \mathrm{mg}^{-1} \mathrm{protein}^{-1}$; $\mathrm{GRx}_{(\mathrm{MF})}: 40.4 \pm 2.8 \mathrm{nmol} \mathrm{NADPH} \cdot \mathrm{min}^{-1} \cdot \mathrm{mg} \mathrm{protein}^{-1} ; \mathrm{GRx}_{(\mathrm{PMF})}: 70.3 \pm 5.1 \mathrm{nmol} \mathrm{NADPH} \cdot \mathrm{min}^{-1} \cdot \mathrm{mg} \mathrm{protein}^{-1}$;

The early overfeeding during lactation did not affect the activity of Grx in liver's MF, GR in liver's MF and PMF (Fig. 1). The same indicators are not significantly changed at the NPs application either (Fig. 2).

Changes in the activity of G-6-PDG and NADP-dependent ICDG in the MF and PMF of liver in animals treated with NPs are not also detected (data are not shown).

Thus, we have found a pronounced positive effect of $\mathrm{GdVO}_{4}: \mathrm{Eu}^{3+} \mathrm{NPs}$ on the prooxidantantioxidant balance in young rats with experimental accelerated aging. The data obtained in this study, as well as those found earlier on the NPs ability to increase survival of elderly rats, prompt to investigate the NPs influences on the state of the prooxidant-antioxidant balance in very old 31-month-old animals with POF. Beginning with the age of 11 months, animals of this group received $\mathrm{GdVO}_{4}: \mathrm{Eu}^{3+} \mathrm{NPs}$ with drinking water within 20 months.

The data presented in Fig. 3 indicate that the concentration of LHPO in the serum and liver MF of these animals decreases by $26.6 \%$ and $32.0 \%$, respectively $(p<0.05)$. At the same time, Aco activity in the MF of the liver is increased by $35.8 \%$ compared to the animals received no NPs.

With the decrease of prooxidant processes, we have observed the increase of the activity of antioxidant enzymes. The activity of GPx of serum, PM of liver in rats with POF, which is much lower than the level of control animals [4, 7], is significantly increased in response to the prolonged use of NPs (Fig. 3), wherein the increases are $21.0 \%$ and $43.4 \%$, respectively. After the prolonged NPs treatment in POF group, the activities of the antioxidant enzymes in liver MF have also been increased. Namely: GPx activity - by $32.6 \%$, Grx - by $33.9 \%$, GR - by $32.0 \%$ 


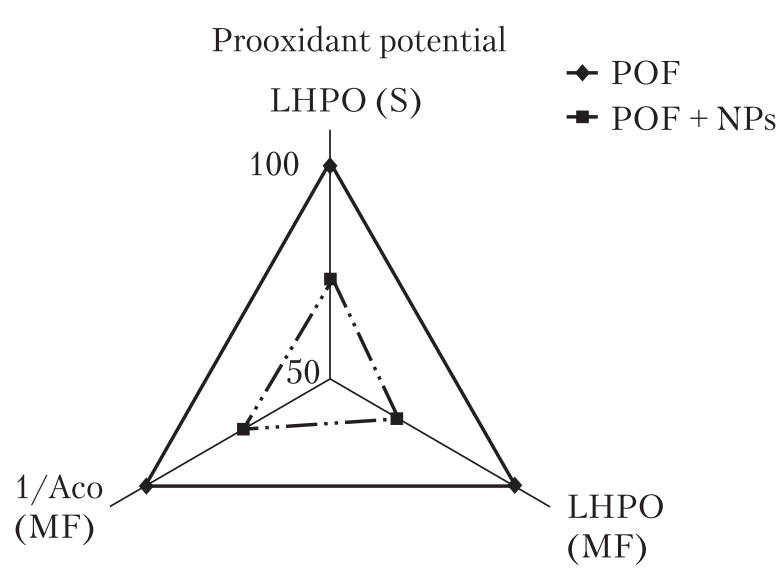

$a$

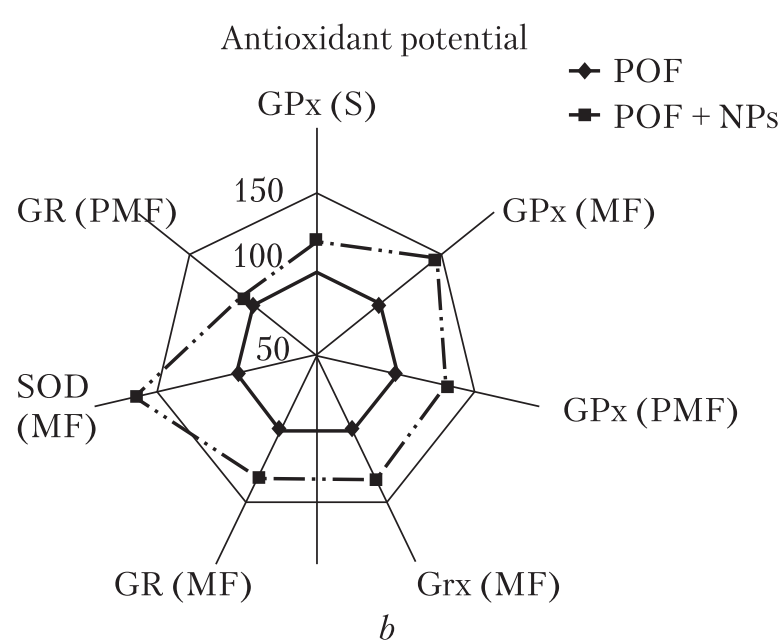

Fig. 3. Prooxidant $(a)$ and antioxidant $(b)$ potentials in serum and liver of 31 months-old rats with accelerated ageing (POF group, $n=7$ ) and after the use of $\mathrm{GdV}_{4}: \mathrm{Eu}^{3+} \mathrm{NPs}$ from 11 months of age (POF $+\mathrm{NPs}, n=7$ ). POF group prooxidant indicators (100\%): $\mathrm{LHPO}_{(\mathrm{S})}: 3.34 \pm 0.11 \mathrm{nmol} \mathrm{MDA} \cdot \mathrm{ml}^{-1} ; \mathrm{LHPO}_{(\mathrm{MF})}: 0.75 \pm 0.08 \mathrm{nmol} \mathrm{MDA} \cdot \mathrm{mg} \operatorname{protein}^{-1}$; $\mathrm{Aco}_{(\mathrm{MF})}: 23.62 \pm 2.69 \mathrm{nmol}$ aconitate $\cdot \mathrm{min}^{-1} \cdot \mathrm{mg}$ protein $^{-1}$;

POF group antioxidant indicators (100\%):

$\mathrm{SOD}_{(\mathrm{MF})}: 36.78 \pm 7.33 \mathrm{c.u} \cdot \cdot \mathrm{mg}$ protein ${ }^{-1}$ CAT $_{(\mathrm{PMF})}: 67.64 \pm 5.25 \mu \mathrm{mol} \mathrm{H}_{2} \mathrm{O}_{2} \cdot \mathrm{min}^{-1} \cdot \mathrm{mg}$ protein $^{-1}$; $\operatorname{GPx}_{(\mathrm{S})}: 4.05 \pm 0.18 \mu \mathrm{mol} \mathrm{NADPH} \cdot \mathrm{min}^{-1} \cdot \mathrm{ml}^{-1} ; \mathrm{GPx}_{(\mathrm{MF})}: 93.77 \pm 12.59 \mathrm{nmol} \mathrm{NADPH} \cdot \mathrm{min}^{-1} \cdot \mathrm{mg}^{\mathrm{PMF}} \operatorname{prein}^{-1}$; $\operatorname{GPx}_{(\mathrm{PMF})}: 427.3 \pm 15.2 \mathrm{nmol} \mathrm{NADPH} \cdot \mathrm{min}^{-1} \cdot \mathrm{mg} \operatorname{protein}^{-1} ; \mathrm{Grx}_{(\mathrm{MF})}: 3.30 \pm 0.42 \mathrm{nmol} \mathrm{NADPH} \cdot \mathrm{min}^{-1} \cdot \mathrm{mg} \operatorname{protein}^{-1}$; $\mathrm{GRx}_{(\mathrm{MF})}: 22.5 \pm 2.4 \mathrm{nmol} \mathrm{NADPH} \cdot \mathrm{min}^{-1} \cdot \mathrm{mg}$ protein $^{-1}$;

and SOD - by $63.3 \%$ ( $p<0.05$, for all indicators). The activity of CAT in liver PMF is not changed significantly compared to control animals.

Thus, the data obtained testify to the positive effect of long-term use of NP - a decrease in the prooxidant and increase in antioxidant potentials both in very old rats at the age of 31 months and in young rats that were overfed during lactation.

The thesis that early overfeeding induces premature aging is confirmed by data on the life expectancy. Studies of rat survival show that it is significantly less in POF animals (Fig. 4, curve 1) compared with normal animals (Fig. 4, curve 2). The median of survival in rats with early postnatal overfeeding is 710 days, while in normal animals -890 days. In this case, the death of the last POF animal is observed by 1000 days and in normal animals - by 1130 days of life. The difference between the survival parameters of these two groups has been evaluated using the Gehan method with the Yates correction, which showed their statistically significant difference. The data on earlier mortality of POF rats are consistent with the data of Frolkis et al. (1992) and our previous results [7].

The use of $\mathrm{GdV0}_{4}: \mathrm{Eu}^{3+} \mathrm{NPs}$ within 20 months (starting from 11 months of age) significantly draws back mortality of POF rats (Fig. 4, curve 3). This effect is especially pronounced the first 350-400 days after the beginning of the NPs introducing. The difference in median of survival between the group of rats with accelerated aging (POF group) and the group POF+NPs is 230 days, and in the days of death of the last animals - 250 days. Comparison of survival by the method of Gehan with the Yates correction revealed a statistically significant difference for all 3 curves. 
Fig. 4. Survival curves of normal rats (curve $1, n=38$,), rats with accelerated aging (curve 2,n=67) and chronic (from 11 months of age) application of the NPs to the rats with accelerated aging - (curve $3, n=49)$

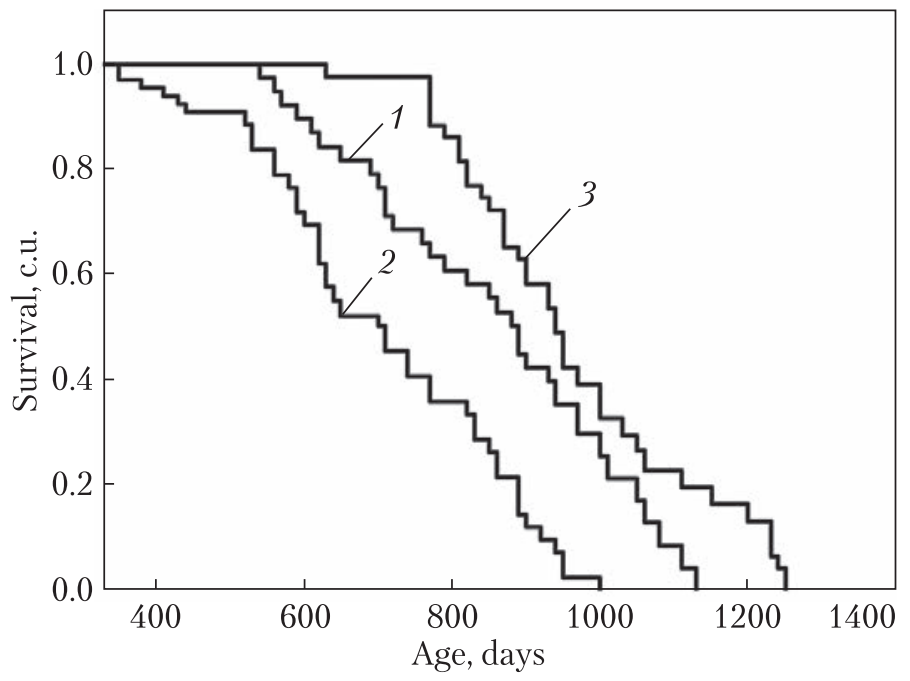

Our earlier studies showed that the prolonged use of $\mathrm{GdVO}_{4}: \mathrm{Eu}^{3+} \mathrm{NPs}$ led to the significant decrease in rectal temperature, to the slower decrease in $\mathrm{T} 4$ levels in the blood of elderly rats, and to the increase in their lifespan [8]. In this work, we found the NPs related significant increase in the survival of senescent animals, with accelerated due to POF ageing. The median survival in the POF group is 710 days, in the POF + NP group -940 days. The death of the last animal from the POF group is observed on day 1000 , and in the group of rats additionally receiving $\mathrm{NPs} \mathrm{GdV0}_{4}: \mathrm{Eu}^{3+}-$ on day 1250 . Thus, these indicators are increased by approximately $-32 \%(p<0.05)$ and $25 \%(p<0.05)$, respectively.

We suggest that $\mathrm{GdVO}_{4}: \mathrm{Eu}^{3+} \mathrm{NPs}$ decrease chronic oxidative stress in model of accelerated ageing inducing the rise of antioxidant potential. The short- and long-term NPs applications are accompanied with normalization of the prooxidant-antioxidant balance in the liver and blood of the POF rats, when the prolonged use of NPs also increases survival and lifespan of the premature ageing rats significantly. Data obtained indicate the promise of $\mathrm{GdVO}_{4}$ : $\mathrm{Eu}^{3+} \mathrm{NPs}$ as a new platform for the development of geroprotector drugs. Furthermore, the corrective influences of NPs in organisms with metabolic programmed risk of adult obesity allow considering them as a new approach to the prevention of associated adverse metabolic health problems.

\section{Conclusions.}

1. In young rats with POF-induced accelerated aging, even the short-term (2 months) using of $\mathrm{GdVO}_{4}: \mathrm{Eu}^{3+} \mathrm{NPs}$ significantly corrects the prooxidant-antioxidant misbalance in liver and blood.

2. In rats with accelerated aging, the prolonged use of NPs from 11 to 31 months of life reduces the disturbances in the prooxidant-antioxidant balance in liver and blood.

3. Prolonged use of gadolinium orthovanadate in the nanoform increases the survival and longevity of senescent rats with accelerated aging. 


\section{REFERENCES}

1. Frolkis, V. V. \& Muradian, K. K. (1991). Life span prolongation. Boston-London: CRC Press.

2. Yu, B. P., Lim, B. O., \& Sugano, M. (2002). Dietary restriction downregulates free radical and lipid peroxide production: plausible mechanism for elongation of life span. J. Nutr. Sci. Vitaminol. (Tokyo), 48, No. 4, pp. 257-264. https://doi.org/10.3177/jnsv.48.257

3. Masoro, E. J. (2000). Caloric restriction and aging: an update. Exp. Gerontol., 35, pp. 299-305. https://doi. org/10.1016/S0531-5565(00)00084-X

4. Nikitchenko, Yu. V., Dzuba, V. M., Popovich, A. S., Bondar, V. V. \& Sheremet, G. O. (2009). Activity of enzymatic antioxidant system in the rat tissues under over- and restricted nutrition. Ukrain. biochem. J., 81, No. 6, pp. 104-110 (in Ukrainian). http://ubj.biochemistry.org.ua/index.php/en/journal-archive/2009-16384/ n-6-november-december-86560/1684-activity-of-enzymatic-antioxidant-system-in-the-rat-tissues-underover-and-restricted-nutrition-yuv-nikitchenko-vn-dzyuba-aspopovich-vv-bondar-aa-sheremet

5. Bozhkov, A. I. \& Nikitchenko, Yu. V. (2013). Caloric restriction diet induces specific epigenotypes associated with life span extension. J. Nutrition. Therapeut., 2, No. 1, pp. 30-39. http://www.lifescienceglobal.com/pms/ index.php/jnt/article/view/693

6. Frolkis, V. V., Grigorov, Yu. G., Pisarchuk, K. L. \& Medovar, B. J. (1992). Influence of overnutrition in postnatal period on aging and life span. Problems of aging and longevity, 2, No. 4, pp. 339-347 (in Russian).

7. Bozhkov, A. I., Nikitchenko, Yu. V. \& Al-Bahadly Ali, M. M. (2016). Overeating in Early Postnatal Ontogenesis Forms Metabolic Memory and Reduces Lifespan. J. Gerontol. Geriatr. Res. 5:3. 9 p. https://doi.org/10.4172/ 2167-7182.1000309

8. Nikitchenko, Yu. V., Klochkov V. K., Kavok, N. S., Karpenko, N. A., Sedych O. O., Bozhkov, A. I., Malyukin Yu. V. \& Semynozhenko V. P. (2020). Gadolinium orthovanadate nanoparticles increase survival of old rats. Dopov. Nac. akad. nauk Ukr., No. 2, pp. 29-36 (in Russian). https://doi.org/10.15407/dopovidi2020.02.029

9. Klochkov, V. K., Malyshenko, A. I., Sedyh, O. O. \& Malyukin Y. V. (2011). Wet-chemical synthesis and characterization of luminescent colloidal nanoparticles: $\mathrm{ReVO}_{4}: \mathrm{Eu}^{3+}(\mathrm{Re}=\mathrm{La}, \mathrm{Gd}, \mathrm{Y})$ with rod-like and spindlelike shape. Funct. Mat., 18, No. 1, pp. 111-115. http://dspace.nbuv.gov.ua/handle/123456789/135437

10. Klochkov, V. K., Grigorova, A. V., Sedyh, O. O. \& Malyukin, Y. V. (2012). Characteristics of $\mathrm{nLnVO}_{4}: \mathrm{Eu}^{3+}$ $(\mathrm{Ln}=\mathrm{La}, \mathrm{Gd}, \mathrm{Y}, \mathrm{Sm})$ sols with nanoparticles of different shapes and sizes. J. Appl. Spectrosc., 79, No. 5, pp. 726-730. https://doi.org/10.1007/s10812-012-9662-7

11. Nikitchenko, Yu. V. (2012). Prooxidant-antioxidant system in ageing processes and experimental approaches to its correction (Extended abstract of Doctor thesis). V. Karasin National University, Kharkiv, Ukraine (in Russian).

12. Averchenko, E. A., Kavok, N. S., Klochkov, V. K. \& Malyukin, Y. V. (2014). Chemiluminescent diagnostics of free-radical processes in an abiotic system and in liver cells in the presence of nanoparticles based on rareearth elements $\mathrm{ReVO}_{4}: \mathrm{Eu}^{3+}(\mathrm{Re}=\mathrm{Gd}, \mathrm{Y}, \mathrm{La})$ and $\mathrm{CeO}_{2}$. J. Appl. Spectrosc., 81, No. 5, pp. 827-833. http:// dx.doi.org/10.1007/s10812-014-0012-9

Received 04.05.2020

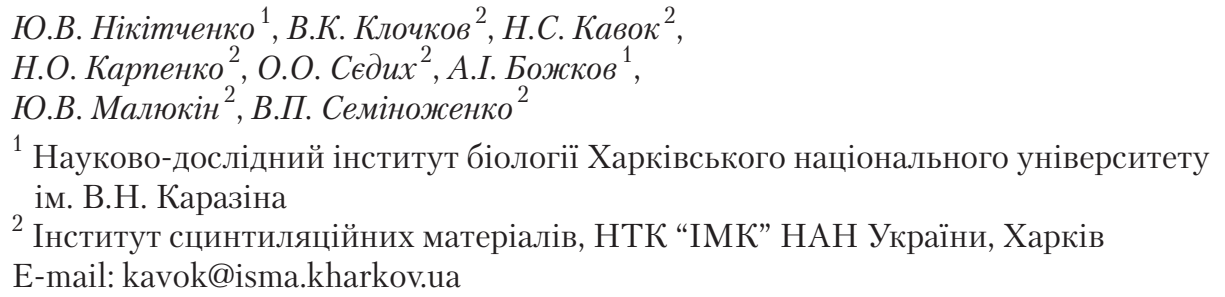

${ }^{1}$ Науково-дослідний інститут біології Харківського національного університету ім. В.Н. Каразіна

2 Інститут сцинтиляційних матеріалів, НТК “ІМК” НАН України, Харків

E-mail: kavok@isma.kharkov.ua

\section{ОРТОВАНАДАТНІ НАНОЧАСТИНКИ СПОВІЛЬНЮЮТЬ ПРИСКОРЕНЕ} СТАРІННЯ ЩУРІВ ЗАПОБІГАЮЧИ ОКСИДАТИВНИМ УШКОДЖЕННЯМ

Досліджено вплив короткочасного й тривалого застосування наночастинок ортованадата гадолінію (НЧ $\mathrm{GdVO}_{4}: \mathrm{Eu}^{3+}, 8 \times 25$ нм) на процеси старіння. Для досягнення мети використовувалася модель прискореного старіння внаслідок надлишкового харчування (HX) в ранньому періоді постнатального онтогенезу; для даної моделі характерним є розвиток окисного дисбалансу та зменшення виживаності тварин й інші 
метаболічні ефекти. НЧ надавали щурам з прискореним старінням перорально (короткочасно або тривалий час) з питною водою. По закінченні досліджували баланс прооксидантів та антиоксидантів (у печінці та крові), виживаність та тривалість життя. У молодих (3-місячних) щурів з прискореним старінням вже короткочасне (2-місяці) надходження НЧ значно коригує окиснювальні порушення. Тривале використання НЧ від 11-го до 31-го місяця життя значно покращує баланс прооксидантних та антиоксидантних реакцій у печінці та крові, порушений НХ. При цьому середня медіана виживаності у контрольній групі становить 890 днів, у групі з прискореним старінням - лише 710 днів, тоді як додаткове отримання НЧ збільшує величину медіани до 940 днів. Крім того, загибель останньої тварини в контрольній групі спостерігалася на 1130 добу, при прискореному старінні - на 1000 добу, а при прискореному старінні при додатковому використанні НЧ - на 1250 добу. Таким чином, обидва показники - виживаність та тривалість життя збільшуються через надання НЧ на 32 та 25 \%, відповідно, у порівнянні з групою прискореного старіння, щурам якої не вводили НЧ. Виявлені ефекти роблять $\mathrm{HЧ} \mathrm{GdVO}_{4}: \mathrm{Eu}^{3+}$, перспективним геропротекторним засобом, що зменшує ризик збільшеної смертності та захворюваності при передчасному старінні, які є несприятливими наслідками надмірного харчування на ранньому етапі постнатального онтогенезу.

Ключові слова: наночастинки $\mathrm{GdVO}_{4} \mathrm{Eu}^{3+}$, надмірне харчування, прискорене старіння, баланс прооксидантів та антиоксидантів, виживаність, тривалість життя, щури самиі. 